\title{
Ceritinib for an anaplastic lymphoma kinase rearrangement-positive patient previously treated with alectinib with poor performance status
}

This article was published in the following Dove Press journal:

OncoTargets and Therapy

\section{Rui Kitadai \\ Yusuke Okuma \\ Shoko Kawai}

Department of Thoracic Oncology and Respiratory Medicine, Tokyo

Metropolitan Cancer and Infectious Diseases Center Komagome Hospital, Bunkyo, Tokyo I I 3-8677, Japan
Correspondence: Yusuke Okuma Department of Thoracic Oncology and Respiratory Medicine, Tokyo Metropolitan Cancer and Infectious Diseases Center Komagome Hospital, 3-18-22 Honkomagome, Bunkyo, Tokyo I I3-8677, Japan

Tel +8I 338232101

Email y-okuma@cick.jp

\begin{abstract}
A L K$ inhibitors are promising for treating $A L K$ rearrangement non-small-cell lung cancer (NSCLC), but secondary mutations of $A L K$ can sometimes inhibit their effectiveness. A 54-year-old woman with lung adenocarcinoma harboring $A L K$ rearrangement previously treated with first-line alectinib and second-line cisplatin/pemetrexed showed poor performance status (PS) with rapid progression. She was treated with ceritinib as salvage treatment, upon which tumor shrinkage was demonstrated on CT and her PS gradually improved. The best supportive care is recommended for patients with advanced NSCLC with poor PS due to lower treatment efficacy and more toxicities than those with good PS. In this case, rapid progression led to a poor PS; however, ceritinib achieved a breakthrough in this case. The optimal treatment sequence and key drugs in $A L K$-positive NSCLC remain controversial.
\end{abstract}

Keywords: anaplastic lymphoma kinase, non-small-cell lung cancer, ceritinib, alectinib, poor performance status

\section{Introduction}

Anaplastic lymphoma kinase (ALK)-positive non-small-cell lung cancer (NSCLC) constitutes $3 \%-7 \%$ of cases of nonsquamous NSCLC, ${ }^{1,2}$ for which the standard care of tyrosine kinase inhibitors (TKIs) has been established. ${ }^{3}$ ALK inhibitors show promising biological and clinical activity, with a response rate of $60 \%$ and progression-free survival (PFS) of 10 months for crizotinib, which is the first-generation ALK inhibitor. ${ }^{4,5}$ Among the second-generation ALK-TKI, alectinib ${ }^{6}$ has also demonstrated superiority in PFS compared with crizotinib for patients with ALK-positive advanced NSCLC; moreover, ceritinib ${ }^{7}$ is superior to platinum-doublet chemotherapy in terms of PFS. Both second-generation ALK inhibitors also demonstrated responses after the acquisition of resistance to crizotinib. ${ }^{8,9}$ As a result, first-line alectinib is considered as the standard of care $^{3}$ with regard to survival and toxicities. The clinical evidences after the acquisition of resistance to alectinib are few as previously stated, but only a Phase II trial of a small cohort with resistance to alectinib has been performed. ${ }^{10}$

The European Society for Medical Oncology recommends only the best supportive care for patients with advanced NSCLC and poor performance status (PS) ${ }^{11}$ because of the associated lower treatment efficacy and more toxicities than those with good PS. ${ }^{12-14}$ However, some study reports that targeted therapy show efficacy to patients with poor PS. In a Phase II study of the EGFR inhibitor gefitinib for EGFR mutation-positive NSCLC patients with poor PS, it was suggested that gefitinib was also clinically active and patients with PS ranging 3-4 showed an improvement in 
PS scores of $0-1$ after treatment in nearly $70 \%$ of cases. ${ }^{15}$ These patients produce a "Lazarus response" when treated with first-line gefitinib. ${ }^{16}$ In patients with advanced NSCLC and EGFR mutation, the median PFS was slightly shorter and the median survival time was much shorter in those with poor PS than in those with good PS. For the ALK inhibitors, a small Phase II study for poor PS also demonstrated positive results in anticipating good responses. ${ }^{17}$ However, no case reports of ceritinib-treated patients previously treated with alectinib, with poor PS, have been published.

We describe the case of a patient with poor PS successfully treated with ceritinib who had been treated with first-line alectinib and second-line platinum-doublet chemotherapy. The patient had approached an end-of-life setting, but had a dramatic response to ceritinib.

\section{Case}

A 57-year-old Japanese woman whose Eastern Cooperative Oncology Group (ECOG) PS was 3, with $A L K$-positive advanced NSCLC with abdominal lymph node (fluorescence in situ hybridization-positive, ALK iScore 3 by iAEP immunohistochemistry) and pleural effusion had been treated with first-line alectinib at a dose of $600 \mathrm{mg}$ daily for 9 months at Tokyo Metropolitan Komagome Hospital. CT scan demonstrated primary tumor in right lower lobe, $70 \mathrm{~mm}$ in diameter, several mediastinal and abdominal lymph node metastases, and plural effusion. Programmed death-ligand 1 expression was $90 \%$ using the $22 \mathrm{C} 3$ antibody. After 4 months, she achieved partial response and her PS improved to ECOG-PS 1; however, CT scan 8 months after introducing alectinib revealed growth of primary tumor and mediastinal lymph node. In the second line, two cycles of cisplatin $\left(75 \mathrm{mg} / \mathrm{m}^{2}\right.$, day 1 , every 3 weeks) and pemetrexed $\left(500 \mathrm{mg} / \mathrm{m}^{2}\right.$, day 1 , every 3 weeks) demonstrated a partial response evaluated by thorax-pelvis CT scan every 2 months; however, upon the completion of four cycles of cisplatin and pemetrexed, rapid progression occurred. CT scan showed growth of primary sites and abdominal lymph node, increase of plural effusion, and emerge of pleural dissemination. Prior to the third line of chemotherapy, the patient was weakened with the ECOG-PS 3 because of anorexia, dyspnea, dysphagia, and cachexia (Figure 1). The pleural effusion was negative for malignancy, and she underwent a blood transfusion for grade 3 anemia (Common Terminology Criteria for Adverse Events Version (CTCAE) version 4.0) due to chronic disorder.

The patient was treated with $600 \mathrm{mg}$ of ceritinib $\left(\right.$ Zykadia $^{\circledR}$ ) under the support of oral ramosetron for the first 5 days and $10 \mathrm{mg}$ of olanzapine daily before sleep. In a few weeks, pleural effusion was gradually reduced and PS was improved. A tumor response was obtained. Grade 2 diarrhea and anorexia (CTCAE version 4.0) were exhibited for a week but were manageable with supportive care. The patient was discharged and seen on an outpatient basis. Her PS improved to ECOG-PS 2; however, she discontinued ceritinib at 6 weeks because of grade 3 increased amylase and grade 2 dysgeusia. Abdominal metastatic lymph node also decreased in size and was assessed as showing partial response according to the Response Evaluation Criteria in Solid Tumors (RECIST version 1.1) for at least 2 months (Figure 2A-D).

\section{Discussion}

We report a dramatic response to ceritinib in a patient with poor PS previously treated with alectinib. The prognosis of patients having $A L K$-positive NSCLC has improved in a decade, and the median survival time is over 5 years in advanced stages. ${ }^{18}$ Over the past years, several generations of ALK inhibitors have been developed and approved by Food and Drug Administration (FDA) including second-generation
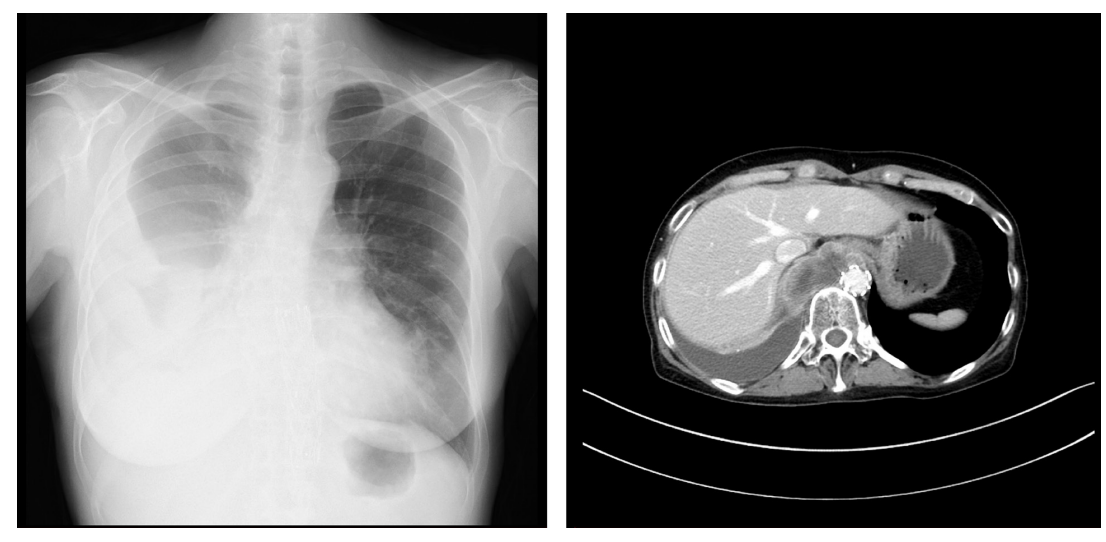

Figure I Chest X-ray and CT scan before treatment with ceritinib. 

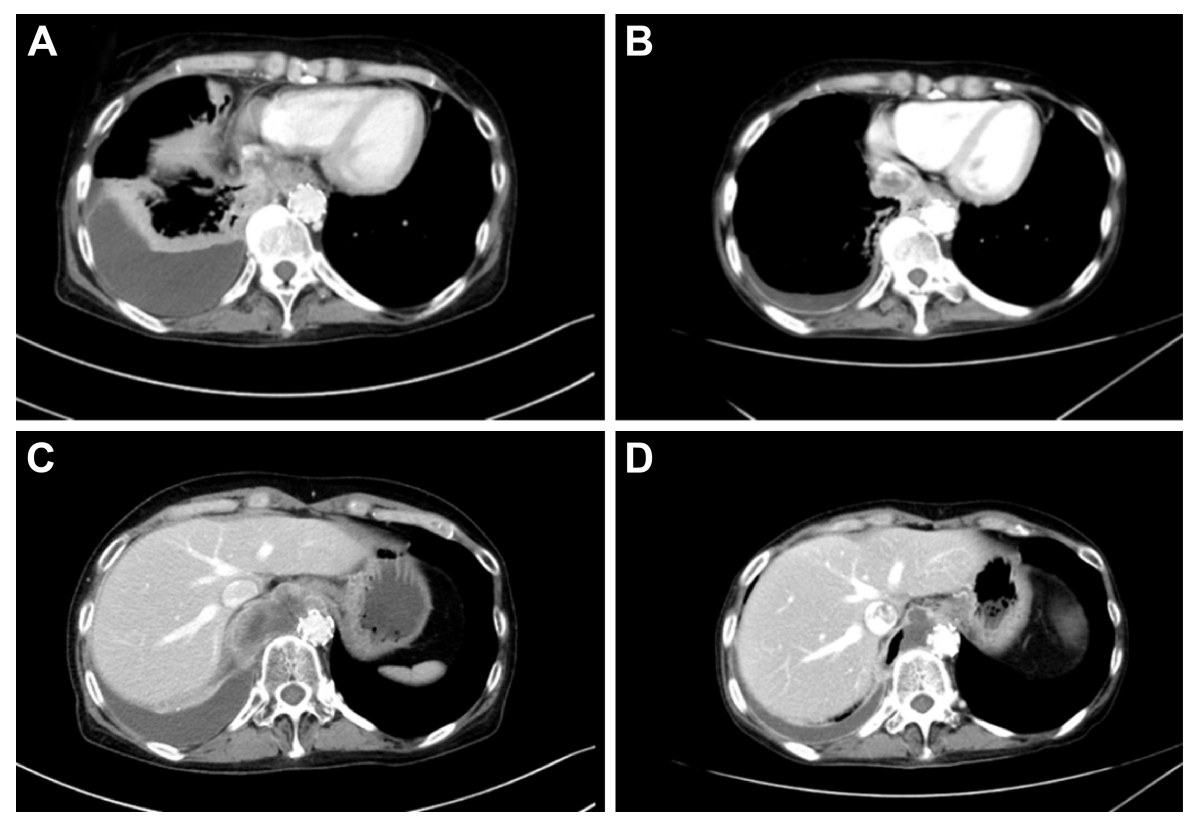

Figure 2 CT scan before introducing ceritinib $(\mathbf{A}, \mathbf{C})$, and 6 weeks after treating with ceritinib (B, D). Reduction of the primary tumor and plural effusion was revealed after the treatment.

(ceritinib, alectinib, and brigatinib), and third-generation inhibitors (lorlatinib). Alectinib consistently showed better effectiveness and lower toxicities than other ALK-TKI in global and Japanese Phase III studies. ${ }^{6,19}$ Several types of resistance to ALK-TKIs have been reported, including those involving secondary mutation of $A L K^{20}$ and activation of other cell proliferation pathways. ${ }^{21,22}$

In the current case, the selection of treatment was difficult. Considering the poor PS, the best supportive care is the standard of care. Considering targeted therapy, ceritinib is the most promising option, although no data on the effects of $A L K$ mutation on such treatment are available. In the ASCEND-9 study in Japanese patients, previously treated with alectinib having $A L K$-positive NSCLC, ${ }^{10}$ the response rate of ceritinib was $25 \%$ (95\% CI: $8.7 \%-49.1 \%$ ) and the median duration of exposure was 3.7 months (range: $0.4-15.1$ ). These Phase II trial results are not extremely promising, but better than those for single-agent cytotoxic chemotherapy. However, we should note the differences from EGFR-TKI and ALK-TKI in previously reported trial data. ${ }^{15,17}$ The response rate is insufficient to improve the PS. There is a need to more precisely predict the effectiveness of ALK inhibitors among patients having $A L K$ secondary mutations. Preclinical data have shown that ceritinib is active against mutations that are resistant to alectinib in ASCEND-9. ${ }^{9}$ Regarding the key drugs for secondary resistance associated with $A L K$ mutations, ALK-TKI for $A L K^{\mathrm{L} 1196 \mathrm{M}}$ have demonstrated activity in vitro ${ }^{23}$ and in clinical practice. ${ }^{24}$ This case might have secondary ALK mutations such as V1180L or I1171T because ceritinib showed effect after acquiring alectinib resistance. ${ }^{25}$ However, patients sometimes do not receive benefit, as revealed by tumor sampling and examination by next-generation sequencing. Blood monitoring for $A L K$ mutations has been considered, ${ }^{26}$ but no examination system has been established, in view of limitations regarding the sensitivity and cost. In one study, it was also reported that $44 \%$ of post-second-generation ALKTKI biopsies were negative for $A L K$ mutations, which may suggest an alternative mechanism of resistance including upregulated bypass signaling or the involvement of epithelialmesenchymal transition. ${ }^{27}$ Numerous examples of bypass signaling activation have been discovered such as EGFR, $K R A S$, and insulin-like growth factor 1 (IGF-1R) ${ }^{28}$ In this case, IGF-1R activation could be the reason for the effect of ceritinib after using alectinib because ceritinib is known to inhibit IGF-1R and ROS1. Moreover, we could assume that ROS1 activation might be related to alectinib resistance as one of the bypass signaling because ceritinib has clinical activity in patients with ROS1-rearranged NSCLC. ${ }^{29}$ In EGFR, osimertinib against T790M detected in tumors or blood samples is the only good model for precision oncology. ${ }^{30}$ In ASCEND-9, ${ }^{9}$ grade $3 / 4$ toxicities were reported in $70 \%$ of patients, including $20 \%$ with diarrhea and $5 \%$ with nausea, with $15 \%$ discontinuing the study. Many studies repeatedly demonstrated increased toxicities among the patients with poor PS. Therefore, decreasing the dose may thus be acceptable for such patients with poor PS. Currently, the revised 
recommended dose is $450 \mathrm{mg} /$ day, whereas previously it was $750 \mathrm{mg} /$ day under fasted conditions.

This case has the limitation stated previously in the precision oncology era. It should be determined whether the future treatment strategy for $A L K$-positive NSCLC should be based on $A L K$ mutation monitoring to precisely select ALK inhibitors. However, as in the present case, it is sometimes necessary to decide on the appropriate chemotherapy empirically because we currently have insufficient time to wait for the results of a rebiopsy and $A L K$ mutations. This situation should be improved when third-generation ALK inhibitors including brigatinib and loratinib become available. ${ }^{31}$ In addition, an improvement in PS makes them candidates for subsequent cytotoxic chemotherapy for longer survival.

\section{Conclusion}

We report a patient with $A L K$-positive NSCLC who had previously been treated with first-line alectinib. Rapid progression led to a poor PS; however, ceritinib here achieved a breakthrough in the clinical situation with a dramatic response, despite the poor PS. There remains controversy about the treatment sequence and key drugs in $A L K$-positive NSCLC.

\section{Acknowledgment}

We thank Enago (https://www.enago.jp/) for the English language review.

\section{Disclosure}

Dr YO report grants, personal fees from Chugai Pharmaceutical Co. during the conduct of the study; personal fees from AstraZeneca, Japan; personal fees, nonfinancial support from Boehringer Ingelheim, Japan; personal fees from Chugai Pharmaceutical Co., outside the submitted work; and Drs RK and SK report no conflicts of interest in this work.

\section{References}

1. Soda M, Choi YL, Enomoto M, et al. Identification of the transforming EML4-ALK fusion gene in non-small-cell lung cancer. Nature. 2007; 448(7153):561-566.

2. Shaw AT, Yeap BY, Mino-Kenudson M, et al. Clinical features and outcome of patients with non-small-cell lung cancer who harbor EML4ALK. J Clin Oncol. 2009;27(26):4247-4253.

3. National Comprehensive Cancer Network. Non Small Cell Lung Cancer (version 7); 2015. Available from: https://www2.tri-kobe.org/nccn/ guideline/lung/english/nonsmall.pdf. Accessed September 2, 2018.

4. Solomon BJ, Mok T, Kim DW, et al; PROFILE 1014 Investigators. First-line crizotinib versus chemotherapy in ALK-positive lung cancer. N Engl J Med. 2014;371(23):2167-2177.

5. Shaw AT, Kim DW, Nakagawa K, et al. Crizotinib versus chemotherapy in advanced ALK-positive lung cancer. N Engl J Med. 2013; 368(25):2385-2394.
6. Peters S, Camidge DR, Shaw AT, et al; ALEX Trial Investigators. Alectinib versus crizotinib in untreated ALK-positive non-small-cell lung cancer. N Engl J Med. 2017;377(9):829-838.

7. Soria JC, Tan DSW, Chiari R, et al. First-line ceritinib versus platinumbased chemotherapy in advanced ALK-rearranged non-small-cell lung cancer (ASCEND-4): a randomised, open-label, phase 3 study. Lancet. 2017;389(10072):917-929.

8. Gadgeel SM, Gandhi L, Riely GJ, et al. Safety and activity of alectinib against systemic disease and brain metastases in patients with crizotinibresistant ALK-rearranged non-small-cell lung cancer (AF-002JG): results from the dose-finding portion of a phase 1/2 study. Lancet Oncol. 2014;15(10):1119-1128.

9. Shaw AT, Kim DW, Mehra R, et al. Ceritinib in ALK-rearranged non-small-cell lung cancer. N Engl J Med. 2014;370(13):1189-1197.

10. Hida T, Seto T, Horinouchi H, et al. Phase II study of ceritinib in alectinibpretreated patients with anaplastic lymphoma kinase-rearranged metastatic non-small-cell lung cancer in Japan: ASCEND-9. Cancer Sci. 2018;109(9):2863-2872.

11. Planchard D, Popat S, Kerr K, et al; ESMO Guidelines Committee. Metastatic non-small cell lung cancer: ESMO Clinical Practice Guidelines for diagnosis, treatment and follow-up. Ann Oncol. 2018;29(Supplement_4):iv192-iv237.

12. Stanley KE. Prognostic factors for survival in patients with inoperable lung cancer. J Natl Cancer Inst. 1980;65(1):25-32.

13. Pater JL, Loeb M. Nonanatomic prognostic factors in carcinoma of the lung: a multivariate analysis. Cancer. 1982;50(2):326-331.

14. Langer C, Lilenbaum R. Role of chemotherapy in patients with poor performance status and advanced non-small cell lung cancer. Semin Oncol. 2004;31(6 Suppl 11):8-15.

15. Inoue A, Kobayashi K, Usui K, et al; North East Japan Gefitinib Study Group. First-line gefitinib for patients with advanced non-small-cell lung cancer harboring epidermal growth factor receptor mutations without indication for chemotherapy. J Clin Oncol. 2009;27(9):1394-1400.

16. Langer CJ. The "lazarus response" in treatment-naive, poor performance status patients with non-small-cell lung cancer and epidermal growth factor receptor mutation. J Clin Oncol. 2009;27(9):1350-1354.

17. Iwama E, Goto Y, Murakami H, et al. Alectinib for patients with ALK rearrangement-positive non-small cell lung cancer and a poor performance status (Lung Oncology Group in Kyushu 1401). J Thorac Oncol. 2017;12(7):1161-1166.

18. Solomon BJ, Kim DW, Wu YL, et al. Final overall survival analysis from a study comparing first-line crizotinib versus chemotherapy in ALK-mutation-positive non-small-cell lung cancer. J Clin Oncol. 2018; 36(22):2251-2258.

19. Hida $T$, Nokihara $H$, Kondo $M$, et al. Alectinib versus crizotinib in patients with ALK-positive non-small-cell lung cancer (J-ALEX): an open-label, randomised phase 3 trial. Lancet. 2017;390(10089):29-39.

20. Choi YL, Soda M, Yamashita Y, et al; ALK Lung Cancer Study Group. EML4-ALK mutations in lung cancer that confer resistance to ALK inhibitors. N Engl J Med. 2010;363(18):1734-1739.

21. Lennerz JK, Kwak EL, Ackerman A, et al. MET amplification identifies a small and aggressive subgroup of esophagogastric adenocarcinoma with evidence of responsiveness to crizotinib. J Clin Oncol. 2011; 29(36):4803-4810.

22. Yamada T, Takeuchi S, Nakade J, et al. Paracrine receptor activation by microenvironment triggers bypass survival signals and ALK inhibitor resistance in EML4-ALK lung cancer cells. Clin Cancer Res. 2012; 18(13):3592-3602.

23. Friboulet L, Li N, Katayama R, et al. The ALK inhibitor ceritinib overcomes crizotinib resistance in non-small cell lung cancer. Cancer Discov. 2014;4(6):662-673.

24. Makuuchi Y, Hayashi H, Haratani K, et al. A case of $A L K$-rearranged non-small cell lung cancer that responded to ceritinib after development of resistance to alectinib. Oncotarget. 2018;9(33):23315-23319.

25. Isozaki H, Takigawa N, Kiura K. Mechanisms of acquired resistance to ALK inhibitors and the rationale for treating ALK-positive lung cancer. Cancers (Basel). 2015;7(2):763-783. 
26. Hofman P. ALK status assessment with liquid biopsies of lung cancer patients. Cancers (Basel). 2017;9(8):E106.

27. Gainor JF, Dardaei L, Yoda S, et al. Molecular mechanisms of resistance to first- and second-generation ALK inhibitors in ALK-rearranged lung cancer. Cancer Discov. 2016;6(10):1118-1133.

28. Lin JJ, Riely GJ, Shaw AT. Targeting ALK: precision medicine takes on drug resistance. Cancer Discov. 2017;7(2):137-155.

29. Lim SM, Kim HR, Lee JS, et al. Open-label, multicenter, phase II study of ceritinib in patients with non-small-cell lung cancer harboring ROS1 rearrangement. J Clin Oncol. 2017;35(23):2613-2618.
30. Oxnard GR, Thress KS, Alden RS, et al. Association between plasma genotyping and outcomes of treatment with osimertinib (AZD9291) in advanced non-small-cell lung cancer. J Clin Oncol. 2016;34(28): 3375-3382.

31. Awad MM, Shaw AT. ALK inhibitors in non-small cell lung cancer: crizotinib and beyond. Clin Adv Hematol Oncol. 2014;12(7):429-439.

\section{Publish your work in this journal}

OncoTargets and Therapy is an international, peer-reviewed, open access journal focusing on the pathological basis of all cancers, potential targets for therapy and treatment protocols employed to improve the management of cancer patients. The journal also focuses on the impact of management programs and new therapeutic agents and protocols on

\section{Dovepress}

patient perspectives such as quality of life, adherence and satisfaction. The manuscript management system is completely online and includes a very quick and fair peer-review system, which is all easy to use. Visit http://www.dovepress.com/testimonials.php to read real quotes from published authors.

Submit your manuscript here: http://www.dovepress.com/oncotargets-and-therapy-journal 